\title{
Marco Polo \\ a jeho znalost asijských jazyků
}

\author{
PhDr. Vladimír Liščák, CSc., DSc. \\ Orientální ústav AV ČR, v. v. i., Praha \\ $\triangle$ vliscak@orient.cas.cz
}

\begin{abstract}
Orientalia Antiqua Nova XXI
ISBN 978-80-261-1039-2

Západočeská univerzita v PIzni, 2021

https://doi.org/10.24132/ZCU.2021.10392-52-59
\end{abstract}




\section{Abstract}

Marco Polo and his knowledge of Asian languages

Marco Polo (1254-1324) claimed (or rather his editors) that he could speak (and read) in other languages in addition to his own, at least five. Although he spoke little Chinese or rather not, he spoke a number of languages used in East Asia at the time - most likely Turkic (in the Kuman dialect: (lingua) tartara; tartaresce; tartaresche), which was also spoken among Mongols, Arabized Persians, Uighurs and perhaps even he knew Mongolian. While communicating with the Great Khan, Marco Polo was almost certainly able to speak and write Mongolian. Marco Polo usually referred to Chinese local names in Persian, so it is very likely that he spoke Persian and was able to read the Arabic script. In addition, Persian was the lingua franca used throughout the region at the time even at Kublai Khan's court. The paper brings some particular examples from Marco's Mss. 
Marco Polo (1254-1324) prohlašoval (či spíše jeho editoři), že umí mluvit (a číst) kromě svého vlastního i v jiných jazycích, nejméně pěti. Nevíme, zda Marco - jehož dovednosti v jeho rodném jazyce (benátštině), jak se zdá, nebyly nikdy silné a byly zcela jistě ovlivněny i tím, že více než půl života byl daleko od domova - čekal na přiležitost, aby své zážitky popsal, nebo zda Rustichello, který je zapsal, využil přiležitosti procvičit si své řemeslo spisovatele.

Nejstarší zachovalá verze je franko-italská verze z počátku 14. století, označovaná jako pařižský rukopis, uložená v Bibliothèque nationale de France (BNF 1116). Franko-italština, známá též jako franko-benátština nebo franko-lombardština, byl literární jazyk použivaný v některých částech severní Itálie od poloviny 13. století do konce 14. století. Jedním z autorů, kteři v ní psali, byl italský romanopisec Rustichello z Pisy (franko-italsky Rustaciaus, italsky Rustichello da Pisa, Rusticiano, Rusticello apod., konec 13./začátek 14. století), který zapisoval vyprávění Marka Pola.

K významným dílům v tomto literárním jazyce patřila vedle Rustichellovy verze Cest Marka Pola (Le Devisement dou monde) i známá Píseň o Rolandovi (La Chanson de Roland, pravděpodobně z 11. století). Rustichellův Román o králi Artušovi (Roman de Roi Artus, kolem roku 1271), který bezprostředně předcházel cestopisu Marka Pola, je první známou artušovskou romancí napsanou italským autorem.

Sepsání Markova vyprávění mělo okamžitý úspěch. Bylo sepsáno v hybridním franko-italském jazyce, který se použival v severní Itálii jako lingua franca, a nakonec bylo přepsáno a přeloženo do každého významného evropského jazyka a dialektu, počínaje verzemi ve staré francouzštině. Dochovalo se asi 150 různých rukopisů, které byly bud' zkrácenou nebo rozšířenou verzí originálu, 
upravenou nebo „vylepšenou“ do té míry, že se často značně liší od originálu. Někdy značně rozsáhlejší verze jsou zajímavými doklady, jaké zdroje měli středověcí editoři či přímo opisovači k dispozici. Máme i českou (respektive moravskou, nebo chcete-li českou s četnými moravismy) verzi z poloviny 15 . století, připisovanou historikovi Vavřinci z Březové (asi 1370-asi 1437).

Marco často zmiňuje, že lidé v některých regionech mluví vlastním jazykem.

Ačkoli uměl jen málo čínsky nebo spiše čínsky vůbec neuměl, mluvil řadou jazyků, které se tehdy ve východní Asii použivaly - s největši pravděpodobností turkičtinou (v kumánském dialektu: (lingua) tartara; tartaresce; tartaresche), kterou se mluvilo i mezi Mongoly, arabizovanými Peršany, Ujgury, a možná uměl i mongolsky.

Protože Marco Polo žil v Číně 17 let, mohl v době, kdy sloužil císaři, získat alespoň základní znalosti čínštiny. Samotný Kublajchán však neuměl čínsky. Ostatně za jeho vlády bylo běžné, že ani úředníci neuměli čínsky, i když čínština byla jedním z hlavních používaných jazyků; dalšími byly: střední mongolština, turkické jazyky, jako např. západní kipčacké dialekty, čagatajština a stará ujgurština, dále perština a další jazyky.

Kublajchán, císař a Velký chán, původem z Mongolska, zřejmě nejspíš použival východní turkičtinu (střední mongolštinu) zapisovanou staroturkickou abecedou založenou na syrské aramejštině. Později se začalo použivat tzv. kvadrátní písmo, odvozené z tibetského písma. Při komunikaci s Velikým chánem Marco Polo téměř jistě dokázal mluvit a psát mongolsky.

\footnotetext{
${ }^{1}$ Vzhledem k tomu, že Mongolové byli v té době nazýváni jako Tatarové, je těžké určit, co vlastně „tatarský jazyk“ u Marka označoval.
} 
Marco Polo zpravidla odkazoval na čínská místní jména v perském jazyce, takže je velmi pravděpodobné, že hovořil persky a dokázal přečíst arabské písmo. Kromě toho perština byla lingua franca použivaná v celém regionu v té době i u Kublajchánova dvora.

Marco Polo často zmiňuje jazyky, kterými mluví lidé v oblastech, které navštívil. Uvedu několik ukázek z rukopisů cestopisu Marka Pola. Ve svém přehledu budu vycházet především z nejstarší, tedy franko-italské verze v edici (Polo 2018), případně i dalších verzí.

První zmínku o Markově znalosti asijských jazyků najdeme v Pipinově latinském překladu ze 14. století, kde editor doplňuje původní text takto (tučně je dopIněný text):

\begin{abstract}
„A když se tento vyslanec dozvěděl, že jsou tam dva zmínění Latinové ${ }^{2}$ a viděl tyto dva bratry, pana Mikuláše a pana Matouše, kteří se již zcela naučili tatarský ${ }^{3}$ jazyk, byl tím velmi ohromen a měl nesmírnou radost..." [Ibique prefatos reperiens uiros, qui iam plene fuerant in lingua tartarica eruditi, supra modum letatus est quod viros latinos nunquam alios viderat, quos tamen videre plurimum affectabat. $]^{4}$
\end{abstract}

\footnotetext{
${ }^{2}$ Jako Latinové nebo Latinci byli ve středověku označováni mezi Byzantinci obyvatelé italských středověkých států, zejména v dobách zostřených vztahů Konstantinopole s námořními republikami, a hlavně při a po Čtvrté křižové výpravě (1202-1204), kdy bylo zřízeno tzv. Latinské císařství, plně ovládané italskými státy, na troskách Byzantské řiše. Též obecné označení pro západní Evropany, kteři vyznávali latinský římský obřad jako odlišný od řeckého obřadu Byzantské řiše.

${ }^{3}$ Tj. mongolský.

${ }^{4}$ Polo 1902, 8, český překlad srv. Polo 1989, 20.
} 
V 6. kapitole, která popisuje, jak se Velký chán vyptával obou bratrů na křestanské záležitosti, najdeme další zmínku o jejich znalosti „tatarštiny“, kterou již zachycuje i franko-italská verze: „A oba bratři, pan Mikuláš a pan Matouš podali krok za krokem úplný a pravdivý popis, mluvili dobře a moudře jako moudří mužové, jimiž byli, kteři dobře znali jazyk Tatarů, totiž tatarštinu.“ [Et messere Nicolau e meser Mafeu lui distrent toute la verité de chascun por soi biern et ordreemant et sajemant come sajes homes qu'il estoient ke bien savoient la lengue de Tartarç et la tartaresce]. ${ }^{5}$

Marco Polo (či spíše vypravěč jeho cestopisu) dále zmiňuje konkrétní znalost asijských jazyků u Marka Pola v 15. kapitole (Jak Velký chán poslal Marka jako svého vyslance. [Comant le Grant Kaan envoie March pour sez messajes]). Text, doplněný z dalších rukopisů, zejména latinské verze ze 14. století a benátské verze, datované 1445 (Biblioteca Civica, Padova) zní v překladu takto: „...zatímco pobýval u dvora Velikého chána, tento mladík, totiž Marco, syn pana Mikuláše, velmi vybraného ducha, si osvojil pozoruhodnou znalost zvyků Tatarů, jejich jazyků a písem ... Pravím vám zcela pravdivě, že neuběhlo mnoho času od jeho príijezdu na dvůr Velikého chána a znal několik jazyků a čtyři další v různých písmech, takže dokázal číst a psát v jakémkoli z těchto jazyků velmi dobře..."

Ve 20. kapitole, věnované Turkménii, uvádí, že (obyvatelé) mluví barbarským jazykem, lišícím se od ostatních.

V následující kapitole, která je věnována Velké Arménii, latinská verze z 15. století, objevená v Toledu v roce 1932 (tzv. rkp Z), doplňuje: „A má svůj vlastní jazyk a cizí řeč, společnou, avšak odlišnou od všech ostatních provincií.“

${ }^{5}$ Polo 2018, 38. 
Podobným způsobem Marco zmiňuje jazyky na řadě dalších míst. Napřiklad u lokality (u Marka provincie) Iškášim ${ }^{6}$ zmiňuje: „,...a má svůj vlastní jazyk.“7 Podobně u Badachšánu uvádí: „...a mají svůj vlastní jazyk.“8 $\mathrm{O}$ něco dále uvádí: „....deset dní cesty na jih od Badachšánu je provincie zvaná Pašaj, ${ }^{9}$ a (obyvatelé) mají svůj vlastní jazyk. ${ }^{10 " ~ R o v n e ̌ z ̌ ~ t a k ~ o b y v a t e l e ́ ~ K a s ̌ m i ́ r u ~}$ „mají svůj vlastní jazyk.“"11 Podobně ve Váchánu v dnešním severozápadním Afghánistánu a přilehlých oblastech Tádžikistánu "mají svůj vlastní jazyk“. ${ }^{12}$ Takto Marco uvádí existenci místních jazyků u řady dalších území. Nemluví o čínštině, s kterou se zřejmě setkal pouze okrajově, jestli vůbec.

Marco Polo uváděl, že navštívil stovky kostelů a viděl tisíce křestanů na východě, kteří vyznávali syrské křestanství („nestoriánstvi“). Ti používali aramejský (syrský) překlad Bible zvaný Pešitta. Marco se tedy pravděpodobně naučil mluvit syrsko-aramejsky a dokázal také číst v tomto jazyce. Mimo jiné projižděl i Tun-chuangem (敦煌, též 墩煌 Dūnhuáng, tehdejší Ša-čou 沙州 Shāzhōu, dosl. „Písečný kraj“), kde bylo živé nestoriánství, a napsal rovněž ,...obyvatelé provincie jsou všichni modláři, i když je pravda, že jsou zde nějací Turci, kteří se přidržují náboženstvi ${ }^{13}$ nestoriánských křestanů, a ... mají svůj vlastní

\footnotetext{
${ }^{6}$ Iškášim (persky/dari Eškāšem) je město na severovýchodě dnešního Afghánistánu v provincii Badachšán.

${ }^{7}$ Vlastní jazyk má dodnes (iškášimský jazyk, škošmī zavuk či ranīzavuk, persky eškāšmī).

${ }^{8} \mathrm{~V}$ Badachšánu se i dnes používá vedle darí (perštiny) a paštštiny i několik místních jazyků.

${ }^{9}$ Pašaj $(P a x a ̄ i)$ je historická oblast ve východním Afghánistánu a částečně i v severozápadním Pákistánu.

${ }^{10}$ Dodnes použivaji vedle paštštiny vlastní jazyk, pašajštinu (persky zabân Paxāyī).

${ }^{11}$ Jedním z hlavních jazyků v Kašmíru je dodnes kašmírština (kạ̄šur, kǒśur).

${ }^{12}$ Dodnes mluví vlastním íránským jazykem, váchánštinou (waxi, x̌ik zik), příbuznou tádžičtině.

${ }^{13}$ Doplněno z rkp. $Z$.
} 
jazyk.“'14 Jeskyně v Mo-kau (莫高窟 Mògāo Kū) u Tun-chuangu, kde byly nalezeny i nestoriánské svitky, byly $v$ době Markovy návštěvy snad ještě funkční (opuštěny byly až po roce 1372), i když tzv. Knihovna („Library Cave“), kde bylo nalezeno množství rukopisů, byla údajně zapečetěna již kolem roku $1000 .^{15}$

\section{Literatura}

Polo, Marco. 1902. Marka Pavlova z Benátek Milion. Dle jediného rukopisu spolu s př́slušným základem latinským. Vydal Dr. Justin V. Prášek. V Praze: Nákladem České akademie císaře Františka Josefa pro vědy, slovesnost a umění.

Polo, Marco. 1989. Milión neboli O zvycích a poměrech ve východních krajích. Přeložil Václav Bahník. Praha: Odeon.

Polo, Marco. 2018. Le Devisement dou monde. 1 Testo, secondo la lezione del codice fr. 1116 della Bibliothèque Nationale de France a cura di Mario Eusebi, 2 Glossario a cura di Eugenio Burgio. Venezia: Edizioni Ca' Foscari (Filologie medievali e moderne 16. Serie occidentale 13).

${ }^{14}$ Tím zmíněným jazykem mohla být tangutština, která se v oblasti používala ještě po pádu Tangutské říše (též Západní Sia 西夏 Xī Xià 1038-1227), až do začátku 16. století, případně ujgurština nebo u nestoriánů syrská aramejština. ${ }^{15} \mathrm{O}$ studiu tunchuangských rukopisů viz např. zde: https://en.wikipedia.org/ wiki/Dunhuang_manuscripts. 